\title{
The Tradition of Consecrating Rice in Pangandaran Sub-District
}

\author{
Lilis Lisdiati ${ }^{1}$, M. Hum Syarif Hidayat ${ }^{2}$, Ishak Abdulhak ${ }^{3} \&$ Mumuh Muchsin $^{4}$ \\ ${ }^{1}$ Universitas Padjadjaran, Indonesia \\ Correspondence: Lilis Lisdiati, Universitas Padjadjaran. E-mail: lilis.lisdiati@gmail.com
}

Received: May 12,2014 Accepted: May 30, $2014 \quad$ Online Published: October 17, 2014
doi:10.5539/ach.v7n1p156
URL: http://dx.doi.org/10.5539/ach.v7n1p156

\begin{abstract}
This research, entitled The Tradition of Consecrating Rice in Pangandaran Sub-district, is excerpted from my dissertation, System of Tools and Technologies for Environmental Conservation with Exocentrism Approach: the Case of Pangandaran Sub-district. Due to the complex nature of the research object, namely its complicated, dynamic and meaningful social situations, it uses qualitative method which, according to Sugiyono (2007:292), is the customary method to address unclear research object. The research aims to describe and understand the social behavior of the Pangandaran sub-district community in treating rice as their source of life starting from its planting, harvesting and, finally, consuming. Data are collected through (a) participatory observation, (b) interview, (d) library research and (d) triangulation. Participatory observation and interview are means to collect primary data from direct sources whereas library research and triangulation are to obtain secondary data from secondary sources and to obtain credible data, respectively. The research finds that (1) rice is believed to be the manifestation of Dewi Pohaci, thus, it has to be treated with full respect, (2) community members in Pangandaran belong to the society who respect their ancestors highly and are fully committed to practicing what have been taught by them, particularly, the tradition to cultivate, (3) rice consecrating ritual in Pangandaran is a part of Sundanese elders' tradition that teaches to highly value rice as the main staple food and to conserve it accordingly.
\end{abstract}

Keywords: consecrating rice, environmental conservation, exocentrism approach

\section{Introduction}

Consisting of thousands of islands, spanning from Sabang to Merauke, Indonesia is famous for its green image because of its vast forests in the equatorial line that play a role as the world's lungs and is, therefore, dubbed as 'the emerald of the equator.' Additionally, it is also called a prosperous nation of gemah, ripah loh jinawi; the land so fertile that every plant species grows well. Satjadibrata (2010:233) goes even further, calling it gemah ripah rea ketan rea keton, tanahna lendo lir bangawan Gangga. Ketan is Sundanese for' is sticky rice, the type of rice, from which most Sundanese would make culinary products such as opak, ranginang, wajit and leumeung. As for 'keton', meaning money, it equals to Rp. 3.15 (Satjadibrata, 2010:198). Thus, rea ketan, rea keton can mean that the country is blessed with abundant crops and financial wealth.

The fertile land provides valuable resources for the people, most of whom are farmers and, thus, makes Indonesia also known as an agrarian country. Living a very simple life and relying solely on crops makes Indonesian farmers become more than close to nature. Their acquaintance with nature is evident, for example, in the fact that they get plentiful amounts of water from natural springs to water their paddy fields but without excessively exploiting them. They believe in a local genius concept, known as 'pamali,' a taboo which is aimed at protecting nature. Pamali is equivalent to a prohibition set by the karuhun or ancestors (Satjadibrata, 2010:277) that would lead to a bad ending, such as punishment from supernatural beings, when the prohibition is violated. Pamali, then, results in forbidden forests called leuweung larangan which the people may enter only with permission and cannot be exploited without wisdom - a concept that help support nature preservation.

Such general phenomenon specifically occurs in Pangandaran where wisdoms of the ancestors are highly valued and upheld. Methods in farming have become traditions of the people in Pangandaran for generations. They believe in consecrating rice, their main staple food, by taking at least three traditional considerations, namely (a) perfect timing to plant the rice, (b) humane treatment for the rice, and (c) extensive rituals for rice cultivation. It is all related to the system of beliefs inherited from the ancestors. Pangandaran elders understand that rice is the manifestation of Dewi Pohaci whose death is highly appreciated. It is said that, from the ground under which she was buried, plants grew robustly - a palm tree grew from where the tombstone was planted; red rice and white rice grew from her right and left eyes, respectively; 
whereas bamboo grew solidly from her bone joints and grass from her hair. This explains the necessity to treat rice humanely for rice is originated from the body of a human being. In doing so, selamatan, a celebration for expressing thankfulness is held to appreciate the paddy at times when rice begins to completely fill its husk (pare keur reuneuh, literally means 'rice in pregnancy'); when rice is harvested; when rice is stored (ngadiukeun pare, literally means 'to make the rice seated'); and when the rice is to be firstly consumed, or called nganyaran.

Such rituals, however, have recently shifted due to several factors, to name but a few (a) Pangandaran's openness to the outer world as it now turns into tourist destination site, (b) rapid information flow, (c) extensive art, science, and technology development, (d) and, lastly, the changing lifestyle of the youth. Those factors gives daring consequence to the shift in the people's paradigm and view on farming tradition and its methods, which leads to the shift in valuing local geniuses inherited by their ancestors and in treating their surroundings. Science and technology, all in all, have desecrated nature, in a sense that nature with its sacredness and magic-religious powers as well as mystery is now dissected by reason and, therefore, lost its mysterious contents and values.

In order to address the unfortunate phenomenon mentioned in the above, research on the consecration of rice and inventory of farming tradition in Pangandaran is conducted.

\section{Analysis}

\subsection{Pangandaran Sub-District, Pangandaran Regency}

Pangandaran is the name of a village, a sub-district, and regency in West Java Province. The subdistrict consists of eight villages, namely Pangandaran, Pananjung, Wonoharjo, Pager Gunung, Babakan, Sidomulyo, Sukahurip, and Purbahayu. As for Pangandaran Regency, with Parigi as its capital, it used to be a part of Ciamis prior to regional spin-off on October 25, 2012. This newly developed regency consists of ten sub-districts, namely Pangandaran, Parigi, Cijulang, Cigugur, Cimerak, Langkaplancar, Sidamulih, Padaherang, Mangunjaya, and Kalipucang.

Pangandaran Regency is geographically strategic - sharing borders with Ciamis Regency and Banjar in the north, Cilacap Regency in the east, and Tasikmalaya Regency in the west, and is adjacent to the Indian Ocean in the south. The sub-district is geographically surrounded by Sidamulih Sub-district in the north, Sidamulih in the west, and Kalipucang in the east. Similarly, it is adjacent to the Indian Ocean in the south.

Speaking on its etymology, Pangandaran consists of two words, pangan and andar, and one affix -an. Pangan is Sundanese, meaning food, whereas andar, when repeated andar-andar, means traveling. The affix -an nominalizes the combined words and emphasizes location. Etymologically similar, pangreureuhan, from the word reureuh, Sundanese: to rest, means resting place. Or, pangeureunan, form the word eureun, Sundanese: to stop, means the place to stop. Thus, Pangandaran can be translated into the place for tourists to get foods or source of food. The topography of Pangandaran consists of land and water - forests and beaches. Sloping gently, Pangandaran beach has mild waves that attract tourists and give numerous advantages for fishermen. Similarly rewarding, the land is suitable for growing various species of plants, such as rice, cassava, and all kinds of vegetables. Palm trees, known for their multiple uses, are popularly grown the south. This is considered as valuable asset by the people of Pangandaran, most of whom choose to be farmers as their livelihood. Methods in farming are traditionally taught from generation to generation, if not derived through enculturation process or trainings from the Office of Agriculture.

\subsection{Tradition of Consecrating Rice}

\subsubsection{System of Belief and Knowledge}

The belief in Goddess Sri, or widely known as Dewi Pohaci in Sundanese regions, was exclusively considered as common knowledge and guidance to performing rituals that would lead to successful farming. According to Suryalaga (2010:8), Sundanese rituals are performed as an order of life that carries cultural values, guiding the people to have a high moral ground.

Almost all Sundanese have strong characters, relying on traditional customs when performing rituals that are full of meaning. For them, treating rice is equal to treating a respected woman for they believe that rice is the manifestation of Dewi Pohaci. They believe that rice must be constantly entertained and comforted. It must not be made upset or hurt. In treating rice, therefore, there are rules, if not prohibitions. The rules state that (a) only women can take peeled rice from where it is stored (padaringan). Men are completely forbidden even to come near the silo; (b) it is forbidden for the women to speak or make any noise while taking rice from padaringan; (c) it is forbidden that rice is wasted, even a tiny grain of it. When a grain of rice is wasted, it will cry. And its tear will anger Dewi Pohaci; (d) male farmers must not whistle near leuit (silo for husked rice) and padaringan (silo for peeled rice). The rules continue as they also prohibit children to (1) nodong dulang or to eat directly from dulang (rice basket) where cooked rice is let cool by fanning; (2) step across centong or a ladle to scoop rice; (3) take cooked rice outside the house without covering it; (4) splatter rice when eating it; and (5) ngokoh or to leave rice on the plate uneaten. 
Furthermore, farmers must carefully organize the timing — finding the right hours to actually start planting. Farmers in Pangandaran recognize bad and good timings by seeing dawuh or time unit. According to them, one day farming consists of 12 hours and 30 minutes, and 5 dawuh or time units, each of which is 2 hours and 30 minutes. The timing is divided as follows

Table I. Time unit division or dawuh

\begin{tabular}{lc}
\hline \multicolumn{1}{c}{ DAWUH } & HOURS \\
\hline Dawuh kahiji (first time unit) & $5.00-7.30$ \\
Dawuh kadua (second time unit) & $7.30-10.00$ \\
Dawuh katilu (thirds ) & $10.00-12.30$ \\
Dawuh kaopat (fourth dawuh) & $12.30-15.00$ \\
Dawuh kalima (fifth dawuh) & $15.00-17.30$ \\
\hline
\end{tabular}

Source: Alil, 75 years old from Pager Gunung 2013.

Dawuh is used to determine the perfect timing for planting or harvesting. For example, harvest is to be done on Thursday Kaliwon (Javanese day). Thursday has 8 points, so does Kaliwon. The addition of the values is 16 . When divided by 5 dawuh, there is one remainder. This, then, is counted randomly or dikerecek, just like playing congklak or a mancala game, using small objects or short sticks or matches. After carefully counted, the result is as follow:

Table II. How to find perfect dawuh for farming

\begin{tabular}{ll}
\hline \multicolumn{1}{c}{ DAWUH } & POINTS \\
\hline Kahiji $5.00-7.30$ & Dua (two) \\
Kadua $7.30-10.00$ & Genep (six) \\
Katilu $10.00-12.30$ & Genep (six) \\
Kaopat $12.30-15.00$ & Hiji (one) \\
Kalima $15.00-17.30$ & Hiji (one) \\
\hline
\end{tabular}

Source: Alil, 75 years old from Pager Gunung, 2013.

The table shows that the perfect dawuh for harvesting is the second and third dawuh for they have the greatest points. Harvesting at those hours will give good and plentiful crops (beuneur, teu hapa).

Besides deciding what time unit would be good for harvesting, days can also be calculated. The calculation is made by summing the points of a day (Senen, Salasa, Rebo, Kemis, Juma'ah, Saptu, Ahad) and the points of its double or Rankepan, which is day names in Sundanese five day week or pasaran (Manis, Pahing, Pon, Wage, Kaliwon). Afterward, the number is divided into four in accordance with the number of the keywords i.e. NYEKSREK, NOYEK, JEMBLONG, KOSONG. Nyeksrek and noyek are considered excellent for this will result in good crops whereas jemblong and kosong will give a result otherwise, if not crop failure.

Table III. How to find the right day for farming

\begin{tabular}{cccc}
\hline DAYS & POINT & RANGKEPAN & POINT \\
\hline Senen (Monday) & 4 & Manis & 5 \\
Salasa (Tuesday) & 3 & Pahing & 9 \\
Rebu (Wednesday) & 7 & Pon & 7 \\
Kemis (Thursday) & 8 & Wage & 4 \\
Juma'ah (Friday) & 6 & Kaliwon & 8 \\
Saptu (Saturday) & 9 & - & - \\
Ahad (Sunday) & 5 & - & - \\
\hline
\end{tabular}

Source: Alil, 75 years old from Pager Gunung, 2013. 
The table is used as reference to determine good day for farming or harvesting. For example, if you are harvesting on Kamis Kaliwon, the total points from the addition of the two days' points are 16. After divided by four, which is the number of the keywords, the calculation falls on kosong or empty and, therefore, harvesting on Kamis Kaliwon not at all recommended as it will only give bad crops, hapa teu beuneur.

\subsubsection{Plowing the Field}

The most important process of cultivating is plowing, which is immediately followed by tebar, or direct seeding. Prior to direct seeding, the seeds must be carefully chosen from the previous harvest or bought from sellers, of which quality is controlled by the government. Tebar or seeding begins with drying the seeds thoroughly and directly under the sun before stored in a gebog and soaked in water at a pond. Afterward, the seeds are taken out of the water and stored in a closed container (dikekeb) and warmed up but not directly under the sun. Some other farmers use different method, i.e. covering the seeds by kapol leaves which can enable temperature increase of the seeds. In two days, tiny buds or sprouts will grow and ready to be planted in the field, or pawinian.

Pawinian is a piece of land in or outside the rice field used to grow rice seeds/sprouts. The land for seeding is prepared by, first, clearing the land from weeds and grass using parang (machete) or pacul (hoe). Afterward, before spreading dried husks (huut badag) over the pawinian, the land is plowed or digged up using the hoe so that it would easily be planted with sprouts. The husks can make the soil fertile as they can play a role as organic fertilizer once they decompose.

The sprouts are carefully removed from the container and evenly planted and covered with soil to keep them from birds or pests. If the seeds are planted in the swampy (leutak) paddy field, they do not have to be covered with soil to protect them from birds or pest for the wetland plays as another means of protection. This process takes 18 to 25 days. Premature seeds when planted will only result in weak sprouts for they contain too much water and cannot grow perfectly. Similarly, seeds that are too old cannot grow well.

Some handful seeds then plucked (didawut), selected, and bundled using thread made of awi tali (bamboo). Each handful of the seeds is called sagindel.

Besides covering the seeds with soil, farmers build seseg or a thin wall made of bamboo surrounding the seeds for protection. Other than building seseg, protection can also be obtained by calculating the day to plant the seeds on which birds or other pests would not come and plague the field. They calculate the days by adding the points each normal day (Senen, Salasa, Rebo, Kemis, Juma'ah, Saptu, Ahad) has to the points of its rangkepan (Manis, Pahing, Rebo, Kemis, Juma'ah, Saptu, Ahad). Afterward they count total points in accordance with the number of keywords i.e. TIKUS, RIUNG, KADAL, and ULA. If the remainder falls on TIKUS, the seeds will be entirely consumed by rats. When the remainder falls on RIUNG, this means worse for the field will plagued by all kinds of pests. But if the calculation falls on KADAL or ULA, the plants will be free from pests. For example, if a farmer wants to plant seeds on Juma'ah Pahing, the total score is 15 points. The calculation will, then, fall on KADAL, which means that farming should continue because the seeds he/she plants will not be consumed by pests.

Furthermore, superstition also occurs when it comes to efforts of making pests go away. Farmers in Pangandaran believe that rats should never be named or mentioned. When they refer to rats, they would use other names, such as nu geulis jeung nu kasep, literally meaning 'the beautiful and the handsome.' If all efforts to keep crops from failing because of pests are not successful, farmers should begin to sef-introspect and see if they have behaved poorly or said unwise words. To overcome this, another ritual called nguyuh has to be performed. The ritual requires that the farmers prepare offerings consisting of endog hayam kampong (boiled eggs), kupat keupeul (rice cake), kupat salamet (rice cake), tangtang angin, kopi pait (black coffee), kopi manis (coffee with sugar), teh manis (sweet tea), teh pait (black tea), rurujakan (fruit salad), and congcot (coned rice), all of which are served in a sanggar, a box made of woven bamboos where those offerings are presented, at the corner of the rice field or in a saung leutik paranti neundeun puncak manik, waktu mimiti dibuat (Satjadibrata, 2010:343). Puncak manik is coned rice with a boiled egg on top (Satjadibrata, 2010: 309).

Once the offerings are served, the farmers burn incenses and, immediately, ask for apologies. Mang Tis, one of the interviewees who provide information for this research, admitted that once performed the ritual and was given a vision through a dream the night after. In his dream he met a handsome man who said to him that his stomach was full he was going home, "panggih jeung jajaka kasep, nyarita "geus wareg, isuk mah rek mulang!". According to him, no rats had returned ever since.

Following pawinian, when the seeds are ready to be planted, another process, called tandur, takes place. Tandur is believed to be a word contracted from ditata bari mundur, which refers to the process of planting rice in a very 
organized manner, making straight lines from side to side, from the front to the back. After tandur, weeding or freeing the rice field from weeds has to be carried out to keep the ground friable on day 10, 20, 30, and 40 .

As the rice grows bigger, the farmers analogize it to pregnancy and, therefore, organize another syukuran, a ceremony of thankfulness. Dewi Pohaci is now pregnant as the husk is filled with rice (pare keur reuneuh). This ritual starts as the male farmers find logs or tree trunks of sulangkar, pacing and kawung leaves to be planted at the corner of the rice field. At the same time, the women offerings that consist of clothing and cosmetics that include kebaya,karembong or carrying cloth, sandal, hand-mirror, facial powder, lipstick, and perfume. Foods are also served; kupat (rice cake) keupeul, kupat salamet, kupat tantang angin, bubur merah (red porridge), bubur putih (white porridge), seven fruit salads or rurujakan, two rice cones or congcot, boiled eggs, black coffee, coffee with sugar, black tea, water, and a piece of white cloth or boeh. When the offerings are complete, the farmers burn incenses and say prayers.

Following syukuran, as rice begins to ripe, another ceremony, called nyangkreb, is held. This ceremony normally starts at four in the afternoon and ends right before it gets dark. The ritual is similar to that of syukuran Dewi Pohaci. The difference lies only in tying seven straws of rice with its leaves. Afterward, the farmers burn incenses and say the following mantra:

Bul kukus acitanana

Pangukusan Dewa Anta

Dewa Anta pangukusan Nyi Pohaci

Huriiip kang langgeng aja kena owah

Kemba wurung kemba rupa

Aja ngaruksak gawe manusa

Nini colongok aki colongok

Aja ngaruksak gawe ingsun

Huriiip kang langgeng aja kena owah

Adi bali buta ari-ari

Buta bang buta kekawah

Sri sawiji ilang sawiji

Tempa aken nama sira

Sukma anu nyangkreb(ena), sukma anu dicangkreb(ena)

Nyi Bagawa Sang Sri, Ki Bagawa Sang Sri

Ulah gimir ulah reuwas dipipit waktu sadawuh

Huriiip kang langgeng aja kena owah.

After saying the mantra, they take seven steps while holding breath. They continue walking clockwise around the rice field and reciting the last part of the mantra. Upon arriving at one corner of the field (juru kotakan), one of the farmer must stop and tie two adjacent trees to each other (nyangreudkeun dua daun pare nu padeukeut) while saying:

Tutup kunci gedong nabi

Ditutup ku Kangjeng Nabi Muhammad

Huriiip kang langgeng aja kena owah

The same ritual is repeated every time they reach another corner of the field. 
On the following day, prior to harvesting the field, another ritual called mimiti is held. This ritual that has to be performed on the right day and date is to make sure that the harvest will give good crop of rice. Spelling the following mantra is part of the mimiti ritual:

Adi bali buta ari-ari

Buta bang buta kekawah

Sri sawiji ilang sawiji

Tempa aken nama sira

Sukma anu mipit(ena), sukma anu dipipit(ena)

Nyi Bagawa Sang Sri, Ki Bagawa Sang Sri

Ulah gimir ulah reuwas dina gedong pasadaran

Huriiip kang langgeng aja kena owah.

\begin{abstract}
After saying the mantra, the farmer must cut with a sickle the seven straws of rice tied during the nyangkreb ritual. The next group of straws must be cut accordingly in groups of fifteen or seventeen. The rice straws firstly harvested in this ritual are called indung pare (the mother of rice), which is said to be able to predict the success of the harvest. If the rice straws are covered by whitish layer, the harvest will give extra crops to the farmers. But if the straws are not covered by the whitish layer, the harvest means otherwise.

The indung pare must now be covered with dirt from the paddy field. The farmers, however, must not use their hands to cover the straws. They are only allowed to take the dirt using his left big toe and, immediately, cover the straws using their right hands. The straws are then wrapped with sulangkar leaves, tied with kawung leaves, and brought home to be stored at leuit.

The rice that has just been harvested has to be dried out under the sun so that the rice has longer durability before it is stored in a silo made of bamboo or wood. Storing husked rice in the leuit is assigned to male farmers and storing peeled rice in the padaringan is the female farmers' responsibility. The process of storing rice in leuit and padaringan is called ngadiukkeun pare or ngadiukkeun beas - another process that also requires mantra as follow:
\end{abstract}

Adi bali buta ari-ari

Buta bang buta kekawah

Sri sawiji ilang sawiji

Tempa aken nama sira

Sukma anu ngadiuk(ena), sukma anu didiuk(ena)

Nyi Bagawa Sang Sri, Ki Bagawa Sang Sri

Ulah gimir ulah reuwas dina gedong pasametan

Huriiip kang langgeng aja kena owah.

Mimiti is followed not long afterward by nganyaran, a ritual of cooking rice from the very first cycle of farming and harvesting (sapanyambut). Rice and side dishes are served; offerings and incense are prepared. When everything is completed and guests have arrived, a feast to show gratefulness begins.

Nganyaran actually begins when rice is placed (ngadiukkeun beas) in padaringan. The process of placing the rice has its own rituals, beginning with the female farmer puts on kemben (shoulder cloth) or karembong (carrying cloth) and kneels, showing respect to Dewi Pohaci. She then puts down the rice. On top of the rice, she pours water into a glass and serves congcot, endog hayam kampong, and hihid (a fan made of woven bamboo). While fanning the rice and the offerings with hihid, she says the following mantra: 
Adi bali buta ari-ari

Buta bang buta kekawah

Sri sawiji ilang sawiji

Tempa aken nama sira

Sukma anu ngadiuk(ena), sukma anu didiuk(ena)

Nyi Bagawa Sang Sri, Ki Bagawa Sang Sri

Ulah gimir ulah reuwas dina gedong padaringan

Huriiip kang langgeng aja kena owah.

It is believed that the rice is fatigued and sweltered and, therefore, has to be given water and cooled down with fanning. Just like Dewi Pohaci, the rice stays longer in the padaringan for it feels comfortable, it is very likely that it will stay longer in the padaringan and will not disappear easily (longlongan).

There is this popular saying among farmers, saeutik mahi, loba nyesa, which means that the crop may be small but it can still feed the entire family. If some farmers face economic hardship and have to sell some rice to deal with the situation, they will take some from leuit and sell it. However, while selling it, the farmer will bid a sad farewell, as if he/she is letting his/her own children go on a journey, and say saeutik mahi loba nyesa semet jalan balik deui (small is enough, a lot remains, hopefully you can find your way back home). Some consider this to be a little bit too hyperbolic, but, this also signifies a strong belief that rice is truly alive with feelings and senses just like human beings.

Sundanese live an organized life. They, too, build strong relationship with god the creator through prayers and rituals and with other human being by caring and giving. They understand that human beings " $k u d u$ daek nulung kanu butuh nalang kanu susah, mere maweh ka sasama" (have to have the willingness to help each other, caring for each other), which has become the main principle of most Sundanese who aim to implement a society that is "Luhung Elmuna, Jembar Budayana, Pengkuh Agamana, Rancage Gawena" (knowledgeable, cultured, devout, and diligent).

\section{Conclusion}

Based on the analysis, this research finds that:

1) The people of Pangandaran believe that rice that gives them the strength they need is the manifestation of Dewi Pohaci. Thus, it is compulsory that rice be treated with respect. It has to be taken care of, examined, and made comfortable through a number of rituals.

2) The people of Pangandaran, too, respect their ancestors, which is evident in their commitment to following traditions, especially that of farming.

3) The ritual of consecrating rice in Pangandaran is a significant part of the Sundanese elders' teaching on farming. It stands on a moral ground that guides the people to appreciate rice as their staple food and never waste it. Crop failure will give negative impacts not only to the farmers but to the society of Pangandaran at large.

\section{Reference}

Adimihardja, K. (1992). Kasepuhan yang Tumbuh di atas yang Luruh. Bandung: Tarsito. Pengelolaan Lingkungan Secara Tradisional di Kawasan Gunung Halimun Jawa Barat.

Ekadjati, E. S. (2009). Kebudayaan Sunda (Suatu Pendekatan Sejarah) Jilid 1. Cetakan Ketiga Jakarta: Dunia Pustaka Jaya.

Ekajati, E. S. (1984). Masyarakat Sunda dan kebudayaannya. Girimukti Pasaka.

Fadjarajani, S. (2009). Dinamika Masyarakat dan Konversi Lahan Pertanian Serta Pengaruhnya Terhadap Pengetahuan Tentang Lingkungan Di KBU. Disertasi. Bandung: Universitas Pendidikan Indonesia.

Hayati, S. (2011). Model Penanaman Nilai-Nilai Kearifan Lokal (Local Genius) pada Masyarakat Sunda dalam Membentuk Perilaku Lingkungan Bertanggung Jawab. Environmental Responsibility Behavior/ERB. Bandung: UPI.

Satjadibrata. (2010). Kamus Basa Sunda. Bandung: Kiblat Buku Utama 
Suryalaga, H. R. H. (2010). Fisafat Sunda Sekilas Interpretasi Langkah Awal Menyimak dan Menyistemi Sasikan Perjalanan Spiritual- Metafisik dalam Folklor Sunda. Bandung: Divisi Penerbitan Yayasan Nur Hidayah.

\section{Informants:}

Alil, 75 years old, resides in Pager Gunung

Asti, 80 years old, resides in Purbahayu

Karnen, 60 years old, resides in Pager Gunung

Tisna, 50 years old, resides in Purbahayu

\section{Copyrights}

Copyright for this article is retained by the author(s), with first publication rights granted to the journal.

This is an open-access article distributed under the terms and conditions of the Creative Commons Attribution license (http://creativecommons.org/licenses/by/3.0/). 